\title{
Urinary incontinence in elderly women from Porto Alegre: its prevalence and relation to pelvic floor muscle function
}

\author{
Incontinência urinária em idosas de Porto Alegre: sua \\ prevalência e sua relação com a função muscular do assoalho pélvico \\ La incontinencia urinaria en mujeres mayores de Porto Alegre: su prevalencia y su \\ relación con la función muscular del piso de la pelvis
}

Chandra da Silveira Langoni', Mara Regina Knorst ${ }^{2}$, Gisele Agustini Lovatel ${ }^{3}$, Valesca de Oliveira Leite ${ }^{2}$, Thais de Lima Resende ${ }^{2}$

\begin{abstract}
I The purpose of this cross-sectional study was to assess the prevalence of self-reported urinary loss in elderly women living in the city of Porto Alegre (Rio Grande do Sul, Brazil), as well as to determine the relation between urinary incontinence (UI) and pelvic floor muscle function (PFMF). It included 270 elderly women (aged from 60 to 92 years) from a population sample, who reported the presence ( $n=155 ; 69.1 \pm 7.8$ years) or absence ( $n=115 ; 67.7 \pm 7.9$ years) of urine loss. Those who reported UI were asked about how long they had been experiencing urinary leakage, the amount of urine lost (drops, jets or complete micturition) and situations in which they lost urine. Out of the total number of individuals, 178 agreed to undergo the assessment of PFMF by means of a perineometry and a bidigital test. The prevalence of elderly women who reported UI (57.4\%) was significantly higher, and the most common isolated situation of urine loss was being unable to get to the toilet in time (26.1\%), and this occurred mainly in drops (52.3\%). The UI lasted for a median of three years. The elderly women with UI had significantly lower PFMF than those without it, regardless of the type of measurement used (perineometry or bidigital test). Therefore, we conclude that, in this sample, UI had a high prevalence and was associated with decreased PFMF.
\end{abstract}

Bearing these findings in mind and taking into account the data available in the literature about the impact of UI on health and quality of life, as well as the low cost of its assessment and treatment, we suggest that the management and care of this dysfunction should be carried out at the Primary Health Care level.

Keywords | Pelvic Diaphragm; Physical Therapy Specialty; Aged; Women's Health.

RESUMO I O objetivo deste estudo foi avaliar a prevalência do relato de perda urinária em idosas residentes no município de Porto Alegre (RS-Brasil), bem como determinar a relação entre incontinência urinária (IU) e a função muscular do assoalho pélvico (FMAP). Participaram 270 idosas (60 a 92 anos) provenientes de uma amostra populacional, que relataram ( $n=155 ; 69,1 \pm 7,8$ anos) ou não ( $n=115$; 67,7 $\pm 7,9$ anos) perda urinária. As idosas que referiram IU foram questionadas quanto a: duração da perda urinária, quantidade de urina perdida (gotas, jato ou completa) e situações em que perdiam urina. Desse total, 178 aceitaram ser submetidas a uma avaliação da FMAP por meio da perineometria e do teste bidigital. A prevalência de idosas com relato de IU (57,4\%) foi significativamente mais elevada, sendo que a situação isolada de perda miccional mais

Study conducted at the School of Nursing, Nutrition and Physical Therapy at Pontifícia Universidade Católica do Rio Grande do Sul (FAENFI/PUCRS) - Porto Alegre (RS), Brazil.

'Specialist in Family and Community Health (Multi-professional Residency), PUCRS - Porto Alegre (RS), Brazil.

${ }^{2}$ FAENFI/PUCRS - Porto Alegre (RS), Brazil.

${ }^{3}$ Universidade Federal de Santa Catarina - Araranguá (SC), Brazil. 
comum foi não conseguir chegar a tempo no banheiro (26,1\%), a qual ocorreu principalmente em gotas (52,3\%). A duração da IU apresentou uma mediana de três anos. As idosas com IU apresentaram FMAP significativamente menor do que aquelas sem, independente da forma de mensuração (perineometria ou teste bidigital). Assim sendo, é possível concluir que, na presente amostra, a IU teve alta prevalência e foi associada a menor FMAP. Tendo esses achados em mente e levando em consideração o conhecimento disponível na literatura sobre o impacto da IU na saúde e na qualidade de vida das pessoas, assim como o baixo custo da sua avaliação e do seu tratamento, sugere-se que o manejo e o cuidado dessa disfunção passem a ser feitos na Atenção Primária à Saúde.

\section{Descritores I Diafragma da Pelve; Fisioterapia; Idoso; Saúde da Mulher.}

RESUMEN I El objetivo de este estudio es evaluar la prevalencia del relato de pérdida urinaria en mujeres mayores residentes en el municipio de Porto Alegre (RS-Brasil), y determinar la relación entre la incontinencia urinaria (IU) y la función muscular del piso de la pelvis (FMPP). Participaron 270 mujeres mayores (60-92 años) las cuales provenían de una muestra poblacional, que relataron ( $n=115 ; 69,1 \pm 7,8$ años) o no ( $n=155$;
67,7×7,9 años) pérdida urinaria. Las mayores que informaron IU fueron interrogadas cuanto a: la duración de la pérdida urinaria, la cantidad de orina perdida (gotas, jet o completa) y las situaciones en las que perdían orina. De este total, 178 aceptaron ser sometidas a una revisión de la FMPP a través de la perineometría y del test bidigital. La prevalencia de mayores que informaron IU (57,4\%) fue significativamente mayor, siendo que la situación aislada de pérdida urinaria más común fue la incapacidad de llegar al baño a tiempo (26,1\%), lo que se produjo principalmente en gotas (52,3\%). La duración de la IU mostró un promedio de tres años. Las mayores con IU presentaron FMPP significativamente más baja que la de las que no tenían IU, independientemente de la forma de medición (perineometría o test bidigital). Por lo tanto, es posible concluir que, en esta muestra, la IU tuvo alta prevalencia y se asoció con una más baja FMPP. Considerando estos resultados y teniendo en cuenta el conocimiento disponible en la literatura sobre el impacto de la IU en la salud y calidad de vida de las personas, así como el bajo costo de su evaluación y su tratamiento, se sugiere que el manejo y cuidado de esta disfunción sean hechos en la Atención primaria de Salud.

Palabras clave I Diafragma Pelvico; Fisioterapia; Anciano; Salud de la Mujer.

\section{INTRODUCTION}

It is estimated that approximately 200 million people worldwide suffer from some type of urinary incontinence (UI). Its prevalence is two times higher among women than men $^{1}$, increases with age, and varies widely, reaching up to $60 \%^{2}$. Thus, due to its prevalence and expressive possibility of leading to increased costs, UI is considered a public health problem ${ }^{3}$.

Although physiological, the ageing process is permeated by increased vulnerability to illnesses that can interfere, among others, with autonomy, mobility, manual dexterity, lucidity, and the functional capability of the lower urinary tract and bladder ${ }^{4}$, all conducive to UI. In this sense, if the steady increase in the population's life expectancy is not followed by improvements in health and quality of life (QOL), it can lead to high public expenditure. Based on this, greater attention can be paid to the management of urinary incontinence through public programs and policies that encourage health promotion and the prevention of this dysfunction ${ }^{5}$.

Among others, UI care involves the assessment of pelvic floor muscle function (PFM), which can be conducted manually or instrumentally ${ }^{6}$. Assessing PFM function is of fundamental importance to approach UI more efficiently, especially among elderly women, given the losses and changes that follow physiological ageing ${ }^{7}$.

However, we found few studies in the national and international literature that assessed and compared the MPF function of elderly women, incontinent or not. Therefore, the present study was conducted with the purpose of determining the prevalence of UI among elderly women in the city of Porto Alegre, as well as evaluating the relation between the muscle function of the pelvic floor and the UI-related accounts provided by these elderly women. The hypotheses of the study were that:

- The number of women with UI would be smaller; and

- Their pelvic floor muscle function would be lower than the women without UI.

\section{METHODOLOGY}

In the present research project, we used data from the "Multidimensional Study on Elderly People from Porto Alegre", carried out as a partnership between a university and the local Health Authority. It had 
a population sample of 1164 elderly people who resided in the community and was conducted between January $3 \mathrm{rd}$ and 27th, 2006. The sample was random and stratified by the census tracts of the municipality.

As can be observed in Figure 1, 270 elderly women ( $\geq 60$ years old) participated in this cross-sectional study. They were asked whether they experienced urine leakage (Do you lose urine without meaning to?) ${ }^{8}$. Those who denied urine leakage were considered continent. Those who reported urine loss were considered incontinent and asked about how long they had experienced urine leakage, the quantity of urine lost (drops, jets or complete micturition), and in what situations they experienced urine loss. Out of the total number of participants, 178 agreed to have their PFM function assessed. The measurement was conducted only once by means of an instrumental assessment (perineometer) and of a bidigital test".

The perineometer used (Kroman - KG 40, São Paulo/SP) measured the intensity of PFM contractions through an intravaginal electrode, which was covered with a disposable and individual condom, and inserted into the participant's vagina $(2-3 \mathrm{~cm})$ while she was in the gynecological position, that is, in the dorsal recumbent position with the lower limbs flexed, apart and supported on the bed. Next, the device was adjusted to zero and the patient was instructed to contract her PFM to the maximum. This procedure was carried out three times, with a 1-minute in-between interval, so as to avoid muscle fatigue. We utilized the highest values obtained. The perineometer's scale varies from zero to $1.75 \mathrm{cmH}_{2} \mathrm{O}$.

The bidigital test was conducted through intravaginal palpation, with a focus on the PFM. The examiner introduced two fingers in the volunteer's vaginal cavity $(2-3 \mathrm{~cm})$ while the latter was in the gynecological position, and requested a maximal contraction. The individual's muscle function was then graded according to Ortiz's scale ${ }^{9}$, ranging from zero (non-responsive perineal function, not even to palpation) to 5 (responsive perineal function, with opposing resistance to palpation that lasted longer than 5 seconds).

The data were analyzed in the program SPSS, version 17.0. The significance level adopted was $5 \%$, and the distribution of data was investigated (KolmogorovSmirnov test). A bivariate analysis between categorical variables was carried out by means of Pearson's chi-square test or Fisher's exact test. To compare the continuous

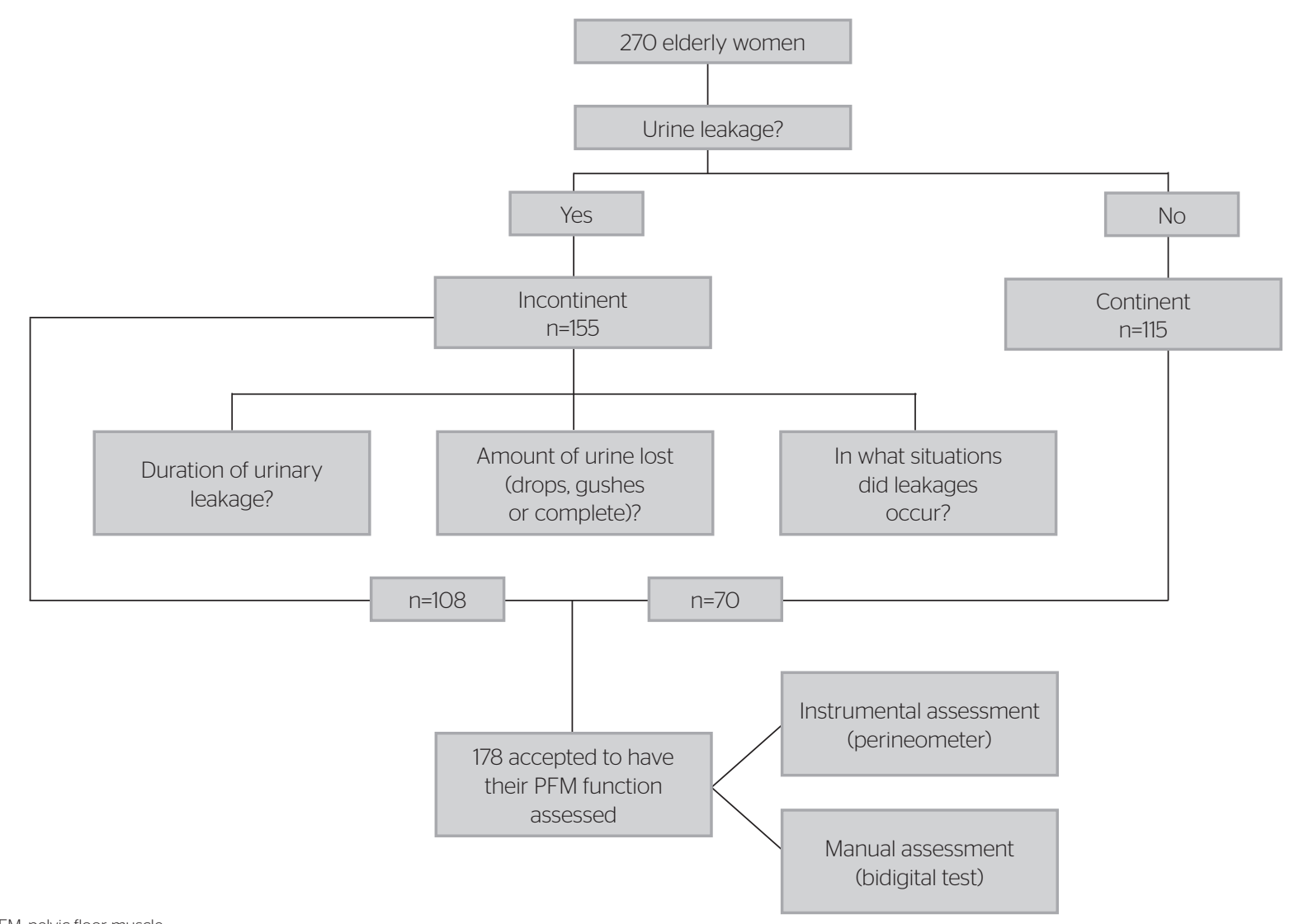

PFM: pelvic floor muscle

Figure 1. Flowchart of the distribution of the total sample 
variables between two independent groups, we used Student's $t$-test and Mann-Whitney's test. When the comparison occurred among three independent categories, we utilized Kruskal-Wallis' test and Dunn's post-hoc test. To evaluate the linearity among the continuous variables, we used Spearman's Correlation Coefficient.

We re-calculated the sample's size after the data obtained from the perineometry and the bidigital test were analyzed by the software samples.exe in the statistical package PEPI, version 4. We considered a power of $80 \%$ and an alpha error of 0.05 . Considering that the perineometry has a standard deviation of $0.3 \mathrm{cmH}_{2} \mathrm{O}$, a sample of 56 women in each group would be necessary to detect a difference of $0.13 \mathrm{cmH}_{2} \mathrm{O}$ between the means. The calculation made with data from the bidigital test indicated a sample size of 62 women.

Considering the other purpose of the study, the sample size calculation indicated that 262 individuals would be necessary to obtain a $95 \%$ confidence interval for the prevalence of UI (57.4\%) with a error of $6 \%$. The confidence interval for the prevalence of UI in the sample varied from 48.8 to $60.6 \%$, with an error of $6 \%$.

This study was approved by the Research Ethics Committee at the university where it was conducted (protocol number 1.066/05-CEP). All volunteers were informed about the nature and proposal of the study, and signed the informed consent.

\section{RESULTS}

In the sample studied here, the prevalence of women with UI was significantly higher (57.4\%). The age average was $68.5 \pm 7.8$ (60 to 92 years), and no statistical differences were detected between the women with and without UI in this regard. The women with UI presented significantly lower PFM function, both in the perineometry and on the bidigital test (Table 1).

Regarding the clinical characteristics of the women with incontinence (Table 2) the median of UI duration was three years. The isolated situation of urine leakage most common among the elderly women was not reaching the bathroom in time $(26.1 \%)$. They also reported losing urine when they coughed (8.5\%), sneezed (3.4\%) or laughed (2\%). However, $60 \%$ of the elderly women with UI reported urine loss in three or more of the aforementioned situations. The most frequent type of leakage happened by drops (52.3\%) followed by jets
(29.4\%), and $18.3 \%$ of the women reported complete micturition.

A positive, moderate and significant correlation was detected between the perineometry and the bidigital test $(\mathrm{r}=0.503, \mathrm{p}<0.001)$.

We did not detect any significant associations ( $p>0.05)$ between situations of urinary loss and the other variables analyzed, regardless of how they were analyzed.

The relation between the quantity of urine lost, the duration of urinary incontinence, and PFM function was also investigated, but no significant associations were detected.

We also investigated whether PFM function was related to UI duration. The results of the perineometry $(r=-0,080)$ and of the bidigital test $(r=-0,080)$ did not present any significant correlations.

Table 1. Age and pelvic floor muscle function of the sample, according to the presence or absence of urinary incontinence

\begin{tabular}{|c|c|c|c|}
\hline \multirow{2}{*}{ Variables } & \multicolumn{2}{|c|}{ Urinary incontinence } & \multirow{2}{*}{ p-value } \\
\hline & Yes & No & \\
\hline Age (years) & $n=155$ & $n=115$ & \\
\hline Mean \pm standard deviation & $69.1 \pm 7.8$ & $67.7 \pm 7.9$ & $0.157^{\star}$ \\
\hline Perineometry $\left(\mathrm{cmH}_{2} \mathrm{O}\right)^{*}$ & $n=108$ & $n=70$ & \\
\hline Median (1st-3rd quartile) & $0.46(0.26-0.69)$ & $0.63(0.35-0.82)$ & $0.044^{* *}$ \\
\hline Bidigital test ${ }^{\S}$ & $n=108$ & $n=70$ & \\
\hline Median (1 $1^{\text {st- }-3^{r d} \text { quartile) }}$ & $3.0(2.0-4.0)$ & $3.0(3.0-4.0)$ & $0.041^{* *}$ \\
\hline
\end{tabular}

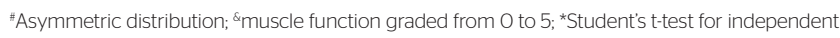
groups; **Mann-Whitney's test

Table 2. Clinical characteristics of the elderly women with urinary incontinence

$\begin{array}{lc}\begin{array}{l}\text { Variables } \\ \text { Duration of urinary incontinence (years) }\end{array} & \begin{array}{c}\text { Total }(\mathrm{n}=155) \\ \mathrm{n}(\%)\end{array} \\ \begin{array}{l}\text { Median (15t-3rd } \text { quartile) } \\ \text { Situation in which urinary loss occurred } \\ \text { Coughing }\end{array} & 3,0(1,0-7,7) \\ \text { Sneezing } & 13(8,5) \\ \text { Laughing } & 5(3,3) \\ \text { Unable to reach the bathroom (urgency) } & 3(2,0) \\ \text { Three or more reasons for urinary loss } & 41(26,1) \\ \text { Amount of urine lost } & 93(60,1) \\ \text { Drops } & 81(52,3) \\ \text { Jets } & 46(29,4) \\ \text { Complete micturition } & 28(18,3)\end{array}$




\section{DISCUSSION}

In the present study, the prevalence of UI reports among women with an average age of $68.5 \pm 7.8$ years, all residents of the city of Porto Alegre (RS), was $57.4 \%$. This prevalence and the age average corroborate the data obtained by Brown et al. ${ }^{10}$, who found a UI prevalence higher than $50 \%$ in a sample of 2,763 women with an age average of 67 years. These results are also similar to the data found by Oliveira ${ }^{3}$, who assessed a sample of 142 elderly women, out of which $61.3 \%$ presented urine leakage, and by Souza et al. ${ }^{11}$, who detected a UI prevalence of $54.9 \%$ among the 153 elderly women investigated. Each prevalence mentioned above, as well as others that are even more recent ${ }^{12,13}$ and above $50 \%$, point to the gravity of this issue among elderly women.

An increase in the prevalence of UI is a fact that has already been determined in a longitudinal study conducted in Norway over a period of 13 years ${ }^{13}$. Unfortunately, a thorough set of records concerning UI is not available in Brazil. However, based on data gathered in the censuses carried out in the country and on different studies about UI prevalence, it is possible to infer that a substantial increase in the number of incontinent elderly women may occur, as reported by Kirby et al. ${ }^{14}$, whose results point to an increase of $72 \%$ in the previous forecast for 2030 in terms of the demand for care concerning pelvic floor dysfunctions in North American women aged over 30 years. Thus, quantifying this increasing demand for care related to UI and pelvic floor dysfunction is important for public health planning and for training professionals in this area, particularly those in Primary Care, the "entrance door" to the Brazilian Health System. It is at this level of healthcare that efforts should be concentrated to develop initiatives that also aim at preventing urinary incontinence.

Upon comparing PFM function, we found that the women with UI presented values significantly lower than those without UI, both in the measurements obtained with the perineometer and with the two-finger palpation. In the research study carried out by Souza et al. ${ }^{11}$, who compared the PFM function of continent and incontinent women with an mean age $(66.71 \pm 5.4$ years) similar to that of the participants of the present study, the incontinent elderly women also presented significantly lower muscle function, both in the measurements obtained with the perineometer and by the two-finger palpation. These findings can be the result of estrogen deficiency and the reduction of collagen fibers that occur with aging ${ }^{15}$. These factors, in turn, cause hypotrophy in the muscle fibers or their replacement by adipocytes, and can thus effectively collaborate for the onset of $\mathrm{UI}^{16}$.

In our study, the two methods used to assess PFM function proved to be equivalent, in accordance with other authors' findings $\mathrm{s}^{6,11,17,18}$. Therefore, it is possible that the use of the bidigital test (a simple, practical and inexpensive method to measure PFM function) combined with pelvic floor kinesiotherapy (also a simple, practical and easy method to be applied) will enable the implementation of UI-related care in the public health system, including its treatment and prevention, as suggested by Knorst et al. ${ }^{19}$ This possibility is even more relevant when we consider the prevalence of UI found in the present study in light of the impact that this dysfunction has on the QOL of individuals affected by it $\mathrm{it}^{2,20,21}$, as stated in several reports found in the literature worldwide.

The most common isolated situation in which the elderly women reported losing urine was not being able to arrive at a bathroom in time, which was characterized as urgency urinary incontinence (UUI) ${ }^{21}$. Few elderly women reported loss of urine in isolated situations that required effort (coughing, sneezing, laughing, etc.), as the majority reported urine loss in three or more of the aforementioned situations, which indicates the severity of UI in these women. The higher prevalence of UUI and mixed UI in the elderly women of this study confirms the findings of other authors ${ }^{12,13,22,23}$.

The elderly women reported having lived with urine leakage for a median of three years, which corroborates the findings of other studies on women, particularly elderly, that state that these individuals live with UI for long periods of time before seeking help $\mathrm{p}^{20,21,24,25}$. Even more concerning is the fact that $25 \%$ of them had been living with UI for 7.7 years or longer without seeking help (Table 2). Considering the innumerable consequences that it can bring to these women's lives, the presence of this dysfunction for such a long time although not putting their lives at risk directly - may bring psychological, economic and social consequences, thus negatively impacting their $\mathrm{QOL}^{26}$. Unfortunately, although it causes affliction and/or limitations to the women who suffer from it, it is only when the loss of urine is very severe that they seek professional help ${ }^{20}$, which not always results in access to information and/ or correct treatment due to several reasons, among them the lack of motivation or knowledge about this condition among health professionals ${ }^{27}$. This context suggests the need for the development of public policies for the management and care of the UI. 
The majority of the women lost urine in drops or jets $(81.7 \%)$, a similar result was found in the studies by Knorst et al..$^{21}$ and Figueiredo ${ }^{28}$, who encountered high occurrence rates when adding both, equivalent to 87.5 and $74 \%$, respectively. Complete micturition was reported by $18.3 \%$ of the women with UI, a similar percentage to the one found by Knorst et al. ${ }^{19}$ (21.7\%). This prevalence reinforces the severity of urine loss and the negative impact that it probably has on the QOL of this group of women ${ }^{2,20,21,26}$. Although expected, the amount of urine lost did not present any association with the duration of urinary incontinence (positive) or with PFM function (negative).

The sample's size was smaller in the comparisons of clinical characteristics and PFM function (with $\mathrm{UI}=108$; without $\mathrm{UI}=70$ ), because there were women (92 out of 270) who did not accept to undergo the gynecological examination. The refusal of $34 \%$ of the elderly women to participate in the assessment of PFM function is one of the limitations of the study, as it may have caused selection bias. Nevertheless, according to the sample size calculation, the study's sample size was sufficient to allow inferences from the findings. It is probable that the refusals to participate in the examination were due to embarrassment, as pointed out by Carvalho and Furegato ${ }^{29}$, since it could not have been because of a longer period of time spent at the test location, as the examination was conducted within the time period the volunteers expected to remain at the university.

The definition chosen for UI is in accordance with the guidelines of the International Continence Society $(\mathrm{ICS})^{8}$. It is a broad definition and, therefore, women with a UI of no clinical importance may have been identified and included in our analyses, which may have led to the high prevalence found here. However, other authors have also found prevalence rates that were similar to or higher than the ones found in this study $y^{3,10,11,12}$, as well as a higher prevalence of functional decline ${ }^{30}$ and of pelvic floor muscle dysfunction ${ }^{7}$ among elderly women with UI.

Health initiative planning draws on epidemiologic data to direct its strategies and actions. Through the use of these data, it is possible to develop measures that can lead to the prevention of the main etiologic causes of a determined disease or dysfunction, and thus positively impact health and QOL, as well as outline a more effective and adequate treatment for the population studied ${ }^{31}$.

As seen in the literature, physical therapy is efficient in reducing urine loss and improving pelvic floor muscle function and QOL. It can be easily carried out in Primary Health Care Units at low costs ${ }^{5,17,19,24}$, either in groups or individually (in the latter case, after approximately 14 treatment sessions ${ }^{24}$ ). Taking into consideration the effectiveness of the physical therapy treatment reported in the literature ${ }^{19,24}$, the high prevalence of UI found among the elderly women in this sample, the connection between UI, functional decline ${ }^{30}$ and falls in the elderly ${ }^{32}$ and the subsequent loss of independence that affects most of the fallers ${ }^{33}$, it is suggested that the elderly users of the public health system should be given access to this therapeutic modality.

\section{CONCLUSION}

It is possible to conclude that, in this sample of elderly women from the city of Porto Alegre, UI had a high prevalence and was associated with decreased PFM function, as assessed by the perineometer and by the bidigital test. Bearing these findings in mind and taking into account the data available in the literature about the impact of UI on health and quality of life, as well as the low cost of its assessment and treatment, we suggest that the management and care of this dysfunction should be carried out at the Primary Health Care level.

\section{REFERENCES}

1. NICE (National Institute of Clinical Excellence). NICE Clinical Guideline 40. Urinary incontinence: the management of urinary incontinence in women [Internet]. 2006. [cited 19/02/2014]. Available from: http:// www.nice.org.uk/nicemedia/pdf/CG4Ofullguideline.pdf

2. Tamanini JT, Lebrão ML, Duarte YA, Santos JL, Laurenti R. Analysis of the prevalence of and factors associated with urinary incontinence among elderly people in the Municipality of São Paulo, Brazil: SABE Study (Health, Wellbeing and Aging). Cad Saúde Pública. 2009;25(8):1756-62.

3. Oliveira DG. Prevalência e fatores associados à incontinência urinária e avaliação da qualidade de vida de idosas incontinentes assistidas por uma unidade básica do sistema público de saúde da família de Recife/PE [dissertação]. Recife (PE): Universidade Federal de Pernambuco; 2012.

4. Farage MA, Miller KW, Berardesca E, Maibach HI. Psychosocial and societal burden of incontinence in the aged population: a review. Arch Gynecol Obstet. 2008:277(4):285-90.

5. Berlezi EM, Bem AD, Antonello C, Leite MT, Bertolo EM. Incontinência urinária em mulheres no período pós-menopausa: um problema de saúde pública. Rev Bras Geriatr Gerontol. 2009:12(2):159-73. 
6. Hundley AF, Wu JM, Visco AG. A comparison of perineometer to brink score for assessment of pelvic floor muscle strength. Am J Obstet Gynecol. 2005;192(5):1583-91.

7. Talasz H, Jansen SC, Kofler M, Lechleitner M. High prevalence of pelvic floor muscle dysfunction in hospitalized elderly women with urinary incontinence. Int Urogynecol J. 2012;23(9):1231-7.

8. Haylen BT, de Ridder D, Freeman RM, Swift SE, Berghmans B, Lee J et al. An International Urogynecological Association (IUGA)/International Continence Society (ICS) joint report on the terminology for female pelvic floor dysfunction. Neurourol Urodyn. 2010, 29:4-20.

9. Ortiz OC, Coya NF, Ibanez G. Evaluación funcional del piso pelviano femenino (clasificación funcional). Soc Latinoam Uroginecol Cir Vaginal. 1996;:1:5-9.

10. Brown JS, Grady D, Ouslander JG, Herzoq AR, Varner RE, Posner SF. Prevalence of urinary incontinence and associated risk factor in postmenopausal woman. Heart \& Estrogen/Progestin Replacement Study (HERS) Research Group. Obstet Gynecol. 1999;94(1):66-70.

11. Souza CEC, Lima RM, Bezerra LMA, Pereira RW, Moura TK, Oliveira RJ. Comparativestudy of pelvic floor function in continent and incontinent postmenopausal women. Braz J Phys Ther. 2009:13(6):535-41.

12. Minassian VA, Stewart WF, Wood GC. Urinary incontinence in women: variation in prevalence estimates and risk factors. Obstet Gynecol. 2008:111(2 Pt 1):324-31.

13. Ebbesen MH, Hunskaar S, Rortveit G. Hannestad YS. Prevalence, incidence and remission of urinary incontinence in women: longitudinal data from the Norwegian HUNT study (EPINCONT). BMC Urol. 2013;13(1):27.

14. Kirby AC, Luber KM, Menefee SA. An update on the current and future demand for care of pelvic floor disorders in the United States. Am J Obstet Gynecol. 2013;209(6):584:1-5.

15. Virtuoso JF, Mazo GZ, Menezes EC. Urinary incontinence and perineal muscle function in physically active and sedentary elderly women. Rev Bras Fisioter. 2011;15(4):310-7.

16. Danforth KN, Townsend MK, Lifford K, Curhan GC, Resnick NM, Grodsten F. Risk factors for urinary incontinence among middle-aged women. Am J Obstet Gynecol. 2006:194(2):339-45.

17. Uyar Y, Baytur YB, Inceboz U. Perineometer and digital examination for assessment of pelvic floor strength. Int J Gynaecol Obstet. 2007;98(1):64-5.

18. Isherwood PJ, Rane A. Comparative assessment of pelvic floor strength using a perineometer and digital examination. BJOG. 2000;107(8):1007-11.

19. Knorst MR, Royer CS, Basso DM, Russo JS, Guedes RG, Resende TL. Quality of life assessment before and after a physical therapy intervention for urinary incontinence. Fisioter Pesqui. 2013;20(3):204-9.
20. Lasserre A, Pelat C, Guéroult V, Hanslik T, Chartier-Kastler E, Blanchon $\mathrm{T}$ et al. Urinary Incontinence in French women: prevalence, risk factors, and impact on quality of life. Eur Urol. 2009;56(1):177-83.

21. Knorst MR, Resende TL, Goldim JR. Clinical profile, quality of life and depressive symptoms of women with urinary incontince attending a university hospital. Rev Bras Fisioter. 2011;15(2):109-16.

22. Silva VA, D’Elboux MJ. Fatores associados à incontinência urinária em idosos com critérios de fragilidade. Texto Contexto Enferm. 2012;21(2):338-47.

23. Coppola L, Caserta F, Grassia A, Mastrolorenzo L, Altrui L, Tondi G et al. Urinary incontinence in the elderly: relation to cognitive and motor function. Arch Gerontol Geriatr. 2002;35(1):27-34.

24. Knorst MR, Resende TL, Santos TG, Goldim JR. The effect of outpatient physical therapy intervention on pelvic floor muscles in women with urinary incontinence. Braz J Phys Ther. 2013;17(5):442-9.

25. Santos CR, Santos VL. Prevalência da incontinência urinária em amostra randomizada da população urbana de Pouso Alegre, Minas Gerais, Brasil. Rev Latinoam Enferm. 2010;18(5):903-10.

26. Viegas K, Welfer M, Lucho GD, Souza CC, Santos BRL, Melo DAS, et al. Qualidade de vida de idosos com incontinência urinária. Rev Ciênc Saúde. 2009;2(2):50-7.

27. Higa R, Lopes $\mathrm{MH}$, Reis MJ. Fatores de risco para incontinência urinária na mulher. Rev Esc Enferm USP. 2008;42(1):187-92.

28. Figueiredo EM, Lara JO, Cruz MC, Quintão DM, Monteiro MV. Sociodemographic and clinical profile of female users of public urogynecological physical therapy services. Braz J Phys Ther. 2008:12(2):136-42.

29. Carvalho ML, Furegato AR. Exame ginecológico na perspectiva das usuárias de um serviço de saúde. Rev Eletrônica Enferm. 2001;3(1). Available from: http://www.fen.ufg.br/revista/revista3_1/gineco.html

30. Omli R, Hunskaar S, Mykletun A, Romild U, Kuhry E. Urinary incontinence and risk of functional decline in older women: data from the Norwegian HUNT-study. BMC Geriatr. 2013;13(1):47.

31. Brasil. Ministério da Saúde. Secretaria-Executiva. Subsecretaria de Planejamento e Orçamento. Sistema de planejamento do SUS: uma construção coletiva - Instrumentos básicos. $2^{2}$ ed. Brasília: Ministério da Saúde; 2009.

32. Moreira MD, Costa AR, Felipe LR, Caldas CP. Variáveis associadas à ocorrência de quedas a partir dos diagnósticos de Enfermagem em idosos atendidos ambulatorialmente. Rev Latinoam Enferm. 2007:15(2):311-7.

33. Secretaria de Estado da Saúde. Relatório Global da OMS Sobre Prevenção de Quedas na Velhice. São Paulo; 2007. [cited 30 Sep 2013] Available from: http://bvsms.saude.gov.br/bvs/publicacoes/ relatorio_prevencao_quedas_velhice.pdf 